\author{
Исторические временные ряды \\ по добыче золота в Российской \\ империи (1741-1917 годы)
}

О.В. Шумилин

B.О. Шумилина*

doi:10.31518/2618-9100-2021-5-4

УДК 94(47)

Выходные данные для цитирования:

Шумилин О.В., Шумилина В.О. Исторические временные ряды по добыче золота в Российской империи (1741-1917 годы) // Исторический курьер. 2021. № 5 (19). С. 40-54. URL: http://istkurier.ru/ data/2021/ISTKURIER-2021-5-04.pdf

\author{
O.V. Shumilin \\ V.O. Shumilina*
}

\section{Historical Time Series \\ for Gold Mining in the Russian \\ Empire (1741-1917)}

doi:10.31518/2618-9100-2021-5-4

How to cite:

Shumilin O.V., Shumilina V.O. Historical Time Series for Gold Mining in the Russian Empire (1741-1917) // Historical Courier, 2021, No. 5 (19), pp. 40-54. [Available online: http://istkurier.ru/ data/2021/ISTKURIER-2021-5-04.pdf]

Abstract. The information presented in the article is the historical time series of the amount of gold mining in the Russian Empire. The research is based on actual data from sources published in pre-revolutionary Russia and the work of L.B. Kafengauz, published in 1994. The article defines the methodological features of the historical time series compilation by the example of gold mining in the Russian Empire: determination of the start and end points of historical time series based on the study of various sources of information containing historical information about the beginning of the gold mining industry in the Russian Empire, taking into account various periodizations of historical processes, as well as specific historical events; ensuring the reliability of historical time series by using both generally accepted reliability criteria (a unified methodology for collecting and processing primary data) and a specific reliability criterion for historical time series (using the most reliable sources of historical statistical information, as well as providing bibliographic references to each level of the time series so that later researchers can check and, if necessary, correct previously compiled historical time series); ensuring the comparability of data in the historical time series compilation by using the same units of measurement, the same time intervals and the spatial database. The use of a unified methodology for the historical time series compilation made it possible to present data on the production of ligature gold, panning gold and pure gold in the Russian Empire in the period from 1745 to 1917, based on the systematization of information from various sources. The article can be used for making historical comparisons according to various social and economic indicators. The article can also be interesting to a wide range of readers interested in the history of our country.

Keywords: gold; gold mining; panning; ligature and pure gold; historical time series.

The article has been received by the editor on 25.05.2021.

Full text of the article in Russian and references in English are available below.

Аннотация. Представленная в статье информация является историческим временным рядом (далее - ИВР) количества добычи золота в Российской империи. В основу исследования положены фактические данные из источников, выпущенных в дореволюционной России, и труд Л.Б. Кафенгауза, вышедший в свет в 1994 г. В статье определены методологические особенности составления исторических временных рядов (ИВР) на примере

\footnotetext{
* Шумилин Олег Валентинович, кандидат экономических наук, доцент, Санкт-Петербургский университет МВД России, Санкт-Петербург, Россия, e-mail: oleg0410@mail.ru

Shumilin Oleg Valentinovich, Candidate of Economic Sciences, Docent, The St. Petersburg University of the Ministry of Internal Affairs of Russia, St. Petersburg, Russia, e-mail: oleg0410@mail.ru

Шумилина Валерия Олеговна, аспирант, Санкт-Петербургский государственный университет, СанктПетербург, Россия, e-mail: shumilina.vo@gmail.com

Shumilina Valeria Olegovna, Post-Graduate Student, St. Petersburg State University, St. Petersburg, Russia, e-mail: shumilina.vo@gmail.com
} 
добычи золота в Российской империи: определение начальной и конечной даты ИВР на основе изучения различных источников информации, содержащих исторические сведения о начале деятельности золотодобывающей промышленности в Российской империи, исходя из разных периодизаций исторических процессов, а также конкретных исторических событий; обеспечение достоверности ИВР путем использования как общепринятых критериев достоверности (единая методология сбора и обработки первичных данных), так и специфического именно для ИВР критерия достоверности (использование наиболее достоверных источников исторической статистической информации, а также приведение библиографических ссылок на каждый уровень временного ряда, для того чтобы в последующем исследователи могли проверить и в случае необходимости скорректировать ранее составленные ИВР); обеспечение сопоставимости данных при формировании ИВР за счет использования единых единиц измерения, одинаковых временных интервалов и пространственной базы. Использование единой методологии подготовки ИВР позволило представить данные о добыче лигатурного, шлихового и чистого золота в Российской империи за период с 1745 по 1917 г. на основе систематизации информации из различных источников. Статья может быть использована при подготовке исторических сопоставлений по различным социальным и экономическим показателям, а также представлять интерес для широкого круга читателей, увлеченных историей нашей страны.

Ключевые слова: золото; добыча золота; шлиховое; лигатурное и чистое золото; исторические временные ряды.

\section{1. Методологические аспекты формирования ИВР по добыче золота}

Под историческим временным рядом (далее - ИВР) понимается последовательность значений статистического показателя, упорядоченных в хронологическом порядке, имеющих обоснованную дату начала и окончания ряда, характеризующих определенный исторический период какой-либо территории и подтвержденных ссылками на источник данных.

Целью статьи является составление ИВР на примере добычи золота в Российской империи, при этом вопросы методологии построения ИВР рассматриваются постольку, поскольку это необходимо для достижения цели публикации. Также в данной статье не ставилась задача объяснить колебания по добыче золота, возникающие в связи с экономическими, политическими, конъюнктурными и другими причинами; объяснить причины расхождений в рассмотренных публикациях.

Для начала остановимся на методологических аспектах формирования ИВР по добыче золота в Российской империи с 1745 г. по 1917 г.

Период ИВР. Для определения периода ИВР в данной работе используется классификация временных рядов, основанная на периодизации возникновения официальных статистических изданий ${ }^{1}$ :

1. Российская империя с 1721 по 1917 г.

2. Российская Советская Республика, РСФСР с 1918 по 1991 г.

3. Российская Федерация - с 1992 г.

В настоящей статье представлены данные по добыче золота только за период существования Российской империи. Исследование о добыче золота и трудностях при изучении этого вопроса после 1917 г. рассмотрено в труде Л.В. Сапоговской ${ }^{2}$. Период с 1992 г. является современным временным рядом и в данной работе также не рассматривается.

Начальная и конечная даты ИВР по добыче золота. Для определения даты начала ИВР по добыче золота в Российской Империи необходимо установить момент начала добычи золота на различных рудниках России.

\footnotetext{
${ }^{1}$ Симчера В.М. Энциклопедия статистических публикаций. Х-ХХ вв. М., 2001. С. 5.

${ }^{2}$ Сапоговская Л.В. Золотопромышленность Республики Советов - СССР - РФ: эволюция отрасли в альтернативных системах хозяйствования. М., 2004. С. 266-308.
} 
В 1787 г. И.Ф. Гакман отмечает ${ }^{3}$, что в Российской империи добыча золота осуществлялась на рудниках, расположенных в Уральских и Алтайских горах, а также в северных горах на полуострове Оце (территория современной Республики Карелии). Далее там же указано, что добыча золота в Уральских горах началась с 1745 г., притом что впервые золото было найдено в 14 верстах от Екатеринбурга в $1743 \Gamma^{4}$.

В исследовании Н.И. Тарасенко-Отрешкова ${ }^{5}$, изданном в 1856 г. и посвященном вопросам добычи золота и серебра в различных странах мира, указано, что в 1744 г. найдена золотая руда в Кемском уезде Олонецкой губернии (территория современной Республики Карелии), для разработки которой был в 1745 г. устроен Воицкий золотой завод.

В труде И. Боголюбского 1877 г. издания утверждается, что впервые золото в России было обнаружено именно в 1732 г. в Архангельской губернии близ деревни Воицкой, а на Алтае в 1736 г. в Змеиногорске были открыты серебросвинцовые руды, содержащие золото ${ }^{6}$.

По данным историко-статистического сборника по вопросам экономического и гражданского развития Алтайского Горного округа ${ }^{7}$, изданного в 1890 г., на Алтае золото впервые было обнаружено на рудниках Демидова в 1742 г., однако выплавка его была впервые осуществлена в Петербурге в 1745 г.

Также имеются и иные исследования золотодобывающей промышленности.

В работе И.П. Берсеневича 1912 г. отмечается, что открытие золота в Алтайских горах можно отнести к 1745 г. ${ }^{8}$

А М.М. Максимов в 1988 г., ${ }^{9}$ обобщая различные источники данных по началу добычи золота в России, со ссылкой на работу В.И. Семевского $1898 \Gamma .^{10}$, писал, что первые указания на наличие золотой руды в Нерчинском крае были получены в 1677 г. Однако далее в той же работе отмечено, что согласно данным И.П. Шарапова ${ }^{11}$ добыча золота в России впервые началась в 1735 г. на Алтае на Змеиногорском руднике. Иные месторождения были открыты позднее: в 1745 г. - на Урале и в Карелии, в 1746 г. было обнаружено золото на Нерчинских рудниках.

О.В. Борхвальдт ${ }^{12}$, проводя исследование о добыче золота и ссылаясь на упомянутого В.И. Семевского, в 1998 г. указала, что первое золото России стали добывать в 1732 г. в Кемском уезде на реке Выге, впадающей в Белое море (Воицкий рудник). Однако далее в ее работе отмечено, что начало развития русского золотого промысла как самостоятельной отрасли относится к 1745 г. и что позднее, в 70-х гг. XVIII в., рудное золото открыто на Алтае в районе Колывано-Воскресенских заводов, а в 1777 г. в Забайкалье.

Таким образом, датой обнаружения первого месторождения золота предлагаем считать 1677 г. датой начала добычи золота в России - 1735 г. а датой начала ИВР по добыче золота - 1745 г., год начала развития русского золотого промысла как самостоятельной отрасли и начала переработки золотой руды на всех важнейших рудниках Российской империи. Датой окончания ИВР по добыче золота в Российской Империи, основанной на предложенной периодизации формирования ИВР, будет 1917 г.

\footnotetext{
${ }^{3}$ Гакман И.Ф. Краткое землеописание Российского государства. СПб., 1787. С. 37.

${ }^{4}$ Тарасенко-Отрешков Н.И. О золоте и серебре: происхождении их, количестве добытом во всех известных странах света с глубокой древности по 1855 год; ныне существующем их накоплении в главнейших государствах и взаимном отношении золота к серебру по их весу и ценности. СПб., 1856. С. 172.

${ }^{5}$ Тарасенко-Отрешков Н.И. О золоте и серебре... С. 171.

${ }^{6}$ Золото, его запасы и добыча... С. 43, 80.

${ }^{7}$ Алтай: историко-статистический сборник по вопросам экономического и гражданского развития Алтайского Горного округа. Томск, 1890. С. 363.

${ }^{8}$ Отчет по статистико-экономическому и техническому исследованию золотопромышленности Томского горного округа. СПб., 1912. Т. 1. С. 103.

${ }_{9}^{9}$ Максимов М.М. Очерк о золоте. М., 1988. С. 63.

${ }^{10}$ Семевский В.И. Рабочие на сибирских золотых приисках // Историческое исследование В.И. Семевского. СПб., 1898. Т. 1: От начала золтопромышленности в Сибири до 1870 года.

${ }^{11}$ Шарапов И.П. Очерки по истории Ленских золотых приисков. Иркутск, 1949.

${ }^{12}$ Борхвальдт О.В. Словарь золотого промысла Российской империи. М., 1998. С. 12.
} 
Достоверность данных при формировании ИВР по добыче золота в Российской империи. Авторы уже отмечали ${ }^{13}$, что необходимым условием обеспечения достоверности при формировании ИВР является выбор источников информации, наиболее заслуживающих доверия, то есть отобранных по результатам ранжирования источников информации по степени достоверности, а также библиографическая ссылка на каждый источник данных.

При составлении ИВР было выявлено, что данные по добыче отдельных видов золота в некоторые периоды времени отсутствуют, в связи с чем имеются пропуски в представленных ниже таблицах (отметки об отсутствии данных (нет данных - н.д.) в ИВР). При сборе исходных данных для формирования ИВР по добыче золота в Российской империи было установлено, что официальные публикации в статистических и ведомственных сборниках содержат информацию о добыче золота с 1814 г. Это обусловлено следующим.

28 мая 1812 г. Правительствующий сенат принял указ под названием «О предоставлении права всем Российским подданным отыскивать и разрабатывать золотые и серебряные руды с платежом в казну подати» ${ }^{14}$, тем самым разрешив добычу золота отдельным сословиям при условии оплаты соответствующего налога в казну. Однако добыча золота вольными старателями до 1814 г. осуществлялась только из коренных месторождений и измерялась весьма небольшими цифрами ${ }^{15}$, крупномасштабная же добыча золота в России началась после находки в 1814 г. золотоносных россыпей ${ }^{16}$. Именно с этим фактом связывают то, что более или менее правильная регистрация получаемого в России золота началась только с 1814 г. ${ }^{17}$

В 1866 г. в предисловии к Статистическому временнику Российской империи отмечено, что сведения о горной промышленности регистрировались весьма удовлетворительно и принадлежали к лучшим материалам для статистики. Причина этого заключалась в том, что добываемое золото и серебро проходило непосредственно через руки казны: закон обязывал золотопромышленников сдавать все добытое ими золото в казну для сплава; а почти все серебряные рудники принадлежали Кабинету Его Величества ${ }^{18}$. Вышесказанное позволяет считать данные по добыче золота в Российской империи, опубликованные в статистических и ведомственных сборниках, достоверными.

Период с 1745 по 1813 г. не охвачен официальными статистическими или ведомственными публикациями. Информация по добыче золота представлена в различных исторических и научных материалах, которые характеризуются следующим: использованием несопоставимых временных интервалов и территорий, отсутствием указания вида добытого золота, неизвестным источником первичной информации. Так, в Энциклопедическом словаре Ф.А. Брокгауза и И.А. Ефрона ${ }^{19}$ данные о добыче золота за период с 1741 по 1800 г. приведены за 20 лет, а за период с 1801 по 1820 г. - за 10 лет. В сочинении И.Ф. Германа ${ }^{20}$ представлены данные по добыче чистого и шлихового золота на Урале за период с 1754 по 1794 г., а в работе 3.Г. Карпенко ${ }^{21}$ имеются данные о выплавке золота в Алтайском горном округе за период 1747-1748 гг. и с пятилетним интервалом за период с 1750 по 1815 г. В работах Е.Ю. Рукосуева и Г.Н. Шумкина ${ }^{22}$ представлены данные о добыче шлихового золота, при этом данные за 1754-1794 гг. заимствованы из уже упомянутого сочинения И.Ф. Германа и

\footnotetext{
${ }^{13}$ Шумилин О.В., Шумилина В.О. Доходы и расходы государственного бюджета Русского царства и Российской империи за 1680-1917 гг., 2018. С. 205.

${ }^{14}$ Указ о предоставлении права всем Российским подданным отыскивать и разрабатывать золотые и серебряные руды с платежом в казну подати от 28 мая 1812 // Полное собрание законов Российской империи, Собрание 1-е. СПб., 1830. Т. 32: 1812-1814, № 25119. С. 328.

${ }^{15}$ Сборник статистических сведений о горнозаводской промышленности России в 1893 заводском году. СПб., 1896. C. XI.

${ }^{16}$ Марфунин А.С. История золота. М., 1987. С. 140.

${ }^{17}$ Общий обзор главных отраслей горной и горнозаводской промышленности: особое приложение к смете Горного департамента на 1916 г. Пг., 1915. С. 1.

${ }^{18}$ Статистический временник Российской империи. СПб., 1866. С. XXV.

19 Энциклопедический словарь. СПб., 1894. Т. 12а. С. 649.

${ }^{20}$ Герман И.Ф. Сочинения о сибирских рудниках и заводах. СПб., 1797. С. 25-38.

${ }^{21}$ Карпенко 3.Г. Горная и металлургическая промышленность Западной Сибири в 1700-1860 годах. Новосибирск, 1963. С. 193.
} 
представляют собой данные «по сплавке чистого золота отправлено в Санктпетербург на Монетный двор с Екатеринбургских золотистых промыслов» ${ }^{23}$.

Кроме того, данные о добыче золота за период с 1754 по 1828 г. по России в целом и на Урале, в частности, приводятся как идентичные с указанием на то, что «все $100 \%$ российского золота добывалось на Урале» ${ }^{24}$. При этом в сочинении И.Ф. Германа также содержатся сведения о добыче шлихового золота на Уральских рудниках (приведены в табл. 5) только за период с 1778 по 1791 г., согласно которым добыча шлихового золота составила 2163 кг. В то время как по данным работы Е.Ю. Рукосуева и Г.Н. Шумкина добыча шлихового золота за тот же период составила 1399 кг.

В работе же 3.Г. Карпенко, опубликованной в 1961 г., содержатся данные о добыче золота на Алтае с 1747 по 1815 г., ${ }^{25}$ которая суммарно за период составила 4806 кг. Так же, как указано выше, в исторических источниках содержатся сведения о добыче золота в конце XVIII в. в Кемском уезде Олонецкой губернии (территория современной Республики Карелии), согласно которым с 1745 по 1794 г. на Воицком руднике было добыто 4 пуда 24 фунта и 68 золотников (75,6 кг) шлихового золота ${ }^{26}$.

К вопросам добычи золота в Восточной Сибири обращался ряд авторов, которые в своих работах приводили данные за отдельные годы, но в целом за рассматриваемый период данные представлены не были. Так, В.П. Зиновьев, обращая внимание на золотопромышленность, давшую толчок развитию Томского края (с. 70), приводит отдельные данные по добыче золота ${ }^{27}$. В диссертационной работе А.И. Митина освещена деятельность кабинетской золотопромышленности на Алтае с 1830 по 1917 г. ${ }^{28}$ М.Н. Мякишев исследовал вопрос о добыче рассыпного золота в Алтайском горном округе в период его аренды Министерством финансов в 1830-1855 гг. ${ }^{29}$, К.У. О-Ун-Дар рассмотрел золотопромышленность Енисейской губернии в период с 1832 по 1917 г. ${ }^{30}$ П.П. Румянцев приводит данные о добыче золота частными золотопромышленниками в восточной части Сибирского региона в середине XIX в. (с. 68, 72). А.П. Суходолов в своих работах (одна из них совместно с М.А. Винокуровым) исследовал добычу золота в дореволюционной России на территории Иркутской области и Восточной Сибири ${ }^{31}$.

Однако все указанные ранее труды, где приведены данные о золотодобыче, характеризуют только отдельные временные периоды и/или конкретизированы по территориальному признаку.

Все установленные выше причины не позволяют объединить приведенные в публикациях данные в единый ИВР по добыче золота в Российской империи, так как будут нарушены требования достоверности и сопоставимости.

\footnotetext{
${ }^{22}$ Рукосуев Е.Ю., Шумкин Г.Н. Золотодобывающая промышленность Урала середины XVIII -начала XX века: периоды развития // Исторический курьер. 2020. № 1 (9). С. 10. URL: http://istkurier.ru/data/2020/ISTKURIER2020-1-01.pdf

${ }^{23}$ Герман И.Ф. Сочинения о сибирских рудниках и заводах... С. 23-24.

${ }^{24}$ Рукосуев Е.Ю., Шумкин Г.Н. Золотодобывающая промышленность Урала...; Рукосуев Е.Ю., Курлаев Е.А., Шумкин Г.Н. Горнозаводская промышленность Урала в XVIII - начале XX века: благородные металлы. Екатеринбург, 2020. С. 64-66.

${ }^{25}$ Карпенко 3.Г. Горная и металлургическая промышленность... С. 193.

${ }^{26}$ Сборник статистических сведений о России, издаваемый статистическим отделением Императорского Русского географического общества. Книжка 1. СПб., 1851. Табл. № 3 к С. 192, 194.

27 Томская область: Исторический очерк. Томск, 1994. С. 70, 88.

${ }^{28}$ Митин А.И. Кабинетская золотопромышленность Алтайского (горного) округа: 1830-1917: дис. ... канд. ист. наук. Барнаул, 2003. 255 с.

${ }^{29}$ Мякишев М.Н. Зарождение и развитие разведки и добычи россыпного золота в Алтайском горном округе в период его аренды Министерством финансов: 1830-1855 гг.: дис. ... канд. ист. наук. Кемерово, 2011. 196 с.

${ }^{30}$ О-Ун-Дар К.У. Золотопромышленность Енисейской губернии с 1832 по 1917 год: дис. ... канд. ист. наук. Красноярск, 2003. 284 с.

${ }^{31}$ Суходолов А.П. Исторические этапы и экономико-географические предпосылки промышленного развития Иркутской области и Восточной Сибири // Иркутский историко-экономический ежегодник: 2015. Иркутск, 2015. С. 30-43; Суходолов А.П. История иркутской золотодобычи // Золото и технологии. 2017. № 4 (38). С. 150-162; Винокуров М., Суходолов А. Золотопромышленность дореволюционной Сибири // ЭКО. 1996. № 5. С. $206-214$.
} 
Таким образом, ИВР по добыче золота в Российской империи был разделен на два периода: с 1745 по 1814 и с 1814 по 1917 г.

Сопоставимость данных при формировании ИВР по добыче золота в Российской империи. Ключевым моментом формирования любого ИВР является сопоставимость данных, т.е. данные, включенные в ИВР, должны быть определены на основе единой методологии. При формировании ИВР по добыче золота было выявлено отсутствие единого подхода к учету исходной информации. В литературе отмечается, что в Российской империи добыча золота учитывалась по трем видам: шлиховое, лигатурное и чистое. При этом данные публиковались как по одному, двум или всем трем видам золота, так и без указания вида добытого золота. Учет добычи золота осуществлялся на основании классификации золота по этапам добычи и переработки. Как в Российской империи ${ }^{32}$, так и в настоящее время по этапам добычи и переработки золото делится на три вида:

- шлиховое (также называемое рассыпным или песчаным) - золото в естественном виде, полученное при окончательной промывке в россыпях, а также самородки;

- лигатурное - рассыпное золото, переплавленное в слитки, то есть золото с примесью других металлов;

- чистое - золото, очищенное от всяких посторонних веществ и металлов.

В настоящее время различие лигатурного и шлихового золота заключается в том, что первое - это сплав золота с химическими элементами, состав которого установлен нормативным документом, а также сплавленное в слитки самородное золото и шлиховое золото; в то время как второе представляет собой неочищенное золото, полученное при гравитационном обогащении песков россыпных руд и/или руд коренных месторождений золота, преимущественно в виде зерен самородного драгоценного металла различной крупности ${ }^{33}$.

С учетом изложенного в работе сформированы три самостоятельных ИВР - в отдельности по каждому виду золота.

В использованных статистических и ведомственных сборниках времен Российской империи данные по добыче и учету золота в России приведены в натуральных единицах измерения с использованием русских мер веса. Для обеспечения сопоставимости данных с более поздними публикациями (см., например, книгу Л.Б. Кафенгауза ${ }^{34}$ ) при составлении ИВР данные о добыче золота были переведены в метрические меры веса. При расчетах были использованы следующие меры веса (массы):

1 пуд равен 40 фунтам или 16,380496 кг.

1 фунт равен 96 золотникам или 409,5124 грамма.

1 золотник равен 4,2657 граммов.

1 доля равна 44,43494 мг

Добыча золота в России осуществлялась на Урале, в Западной и Восточной Сибири, в Пермской и Оренбургской губерниях, Алтайском и Амурском округах и других регионах. В Финляндии добыча золота началась в 1870 г. ${ }^{36}$

Несмотря на то, что добыча золота на территории Финляндии была незначительна ${ }^{37}$, с 1870 г. данные о количестве добытого золота в Финляндии включались в сводные данные о добыче золота в России. С учетом необходимости обеспечить сопоставимость данных по территории, далее в ИВР по добыче золота в Российской империи в общее количество добытого золота включены данные по Финляндии.

Справочно приведем данные о добыче золота в Финляндии за 1870-1908 гг. (табл. 1).

\footnotetext{
32 Тарасенко-Отрешков Н.И. О золоте и серебре... С. 200.

${ }_{33}$ Металлы драгоценные. Термины и определения. ГОСТ Р 52793-2007. Издание официальное. М., 2019. С. 2-3.

${ }^{34}$ Кафенгауз Л.Б. Эволюция промышленного производства России. М., 1994. 848 с.

${ }^{35}$ Статьи 1, 2 Положения о системе Российских мер и весов, Высочайше утвержденного 04.06.1899 (Собр. Узак. 1899 г. Августа 5, ст. 1322) // Полное собрание законов Российской империи: собрание третье. СПб., 1902. T. XIX: 1899. № 17056. С. 622.

${ }^{36}$ Кеппен А.П. Статистический очерк горной промышленности России с 1860 по 1877 год. СПб., 1880. С. 8.

${ }^{37}$ Сборник статистических сведений о горнозаводской промышленности России. 1908 г. СПб., 1917. С. 21.
} 
Таблица 1

Добыча золота в Финляндии, кг

\begin{tabular}{|c|c|c|c|c|c|}
\hline Год & Добыто золота & Год & Добыто золота & Год & Добыто золота \\
\hline 1870 & 19,03 & 1884 & 0,00 & 1898 & 4,53 \\
\hline 1871 & 56,55 & 1885 & 6,14 & 1899 & 2,62 \\
\hline 1872 & 55,03 & 1886 & 4,76 & 1900 & 2,18 \\
\hline 1873 & 32,02 & 1887 & 6,78 & 1901 & 1,97 \\
\hline 1874 & 22,93 & 1888 & 13,52 & 1902 & 2,90 \\
\hline 1875 & 16,98 & 1889 & 22,83 & 1903 & 2,99 \\
\hline 1876 & 9,42 & 1890 & 17,86 & 1904 & 2,02 \\
\hline 1877 & 7,06 & 1891 & 8,77 & 1905 & 0,92 \\
\hline 1878 & 5,76 & 1892 & 4,91 & 1906 & 2,47 \\
\hline 1879 & 8,18 & 1893 & 4,12 & 1907 & 3,56 \\
\hline 1880 & 17,61 & 1894 & 6,47 & 1908 & 2,50 \\
\hline 1881 & 20,16 & 1895 & 9,93 & 1909 & 6,14 \\
\hline 1882 & 19,13 & 1896 & 7,00 & 1910 & 5,32 \\
\hline 1883 & 10,10 & 1897 & 4,59 & 1911-1917 & н.д. \\
\hline
\end{tabular}

Составлено по: 1870-1908. Сборник статистических сведений о горнозаводской промышленности России. 1908 г. Пг., 1917. С. 22-23; 1909-1910. Сборник статистических сведений о горнозаводской промышленности России в 1911 году. Пг., 1918. С. VI.

Таким образом, можно сформулировать основные отличия составления ИВР от простого временного ряда, обусловленные спецификой использования исторических данных:

- необходимо привести исторически обоснованную начальную и конечную точки отсчета периода динамики показателя, периодизацию ИВР;

- с учетом исторических событий провести тщательный анализ на предмет соблюдения требований к сопоставимости данных, используемых в ИВР, обращая внимание на используемые единицы измерения и территориальные признаки анализируемого показателя;

- при составлении ИВР используются не только данные государственной и ведомственной статистики, но и исторические источники информации: архивные данные, исторические монографии и исследования;

- для соблюдения принципа достоверности данных при формировании ИВР нужно указывать источники данных по каждому году или периоду времени и обращать внимание на сопоставление данных, имеющихся в различных источниках информации, в т.ч. с целью выявления расхождений данных между ними, выбора наиболее достоверных сведений, обоснования такого выбора.

\section{2. ИВР по добыче золота в Российской империи}

Добыча золота в Российской империи в период с 1745 по 1814 г. Как указано выше, данные о добыче золота в Российской империи в период с 1745 по 1814 г. имеют разрозненный несистематический характер, отличительными чертами которого являются следующие особенности:

- информация о добыче золота содержится в энциклопедических и научных работах в сводном виде;

- в публикациях зачастую не содержится указания вида добытого золота (шлиховое, лигатурное или чистое);

- имеются разночтения между различными источниками данных о том, что понимается под тем или иным видом золота; 
- часть данных о добыче золота формировались отдельно по каждому региону добычи золота (Уральские и Алтайские рудники; наиболее ранние данные о добыче золота в Олонецком уезде удалось обнаружить только в публикации 1895 г.);

- официальные статистические публикации о добыче шлихового золота начали издаваться с 1858 г.

Справочно приведем данные о добыче золота в период 1745-1813 г. так, как они содержатся в различных публикациях (табл. 2-6).

Таблица 2

Количество золота добытого Россией с 1745 по 1825 г.

\begin{tabular}{|c|c|c|c|}
\hline \multirow{2}{*}{ Годы } & \multicolumn{3}{|c|}{ Добыто золота } \\
\cline { 2 - 4 } & Пудов & Килограмм & В среднем за период, кг \\
\hline $1745-1809$ & 1560 & 25554 & 393 \\
\hline $1810-1825$ & 1004 & 16446 & 1096 \\
\hline
\end{tabular}

Составлено по: Тарасенко-Отрешков Н.И. О золоте и серебре: происхождении их, количестве добытом во всех известных странах света с глубокой древности по 1855 год; ныне существующем их накоплении в главнейших государствах и взаимном отношении золота к серебру по их весу и ценности. СПб., 1856. С. 229.

В труде И. Боголюбского представлены данные по добыче лигатурного золота по царствованиям русских государей (табл. 3).

Количество лигатурного золота по царствованиям русских государей

\begin{tabular}{|l|c|c|c|c|}
\hline $\begin{array}{c}\text { Русские } \\
\text { государи }\end{array}$ & $\begin{array}{c}\text { Годы } \\
\text { правления }\end{array}$ & $\begin{array}{c}\text { Число лет } \\
\text { добычи золота }\end{array}$ & $\begin{array}{c}\text { Добыто } \\
\text { золота, кг }\end{array}$ & $\begin{array}{c}\text { Средняя добыча } \\
\text { золота, кг в год }\end{array}$ \\
\hline Елизавета I & $1741-1761$ & 13 & 83 & 6,4 \\
\hline Петр III & $1761-1762$ & 1 & 26 & 25,7 \\
\hline Екатерина II & $1762-1796$ & 33 & 3136 & 95,0 \\
\hline Павел I & $1796-1801$ & 4 & 973 & 243,1 \\
\hline Александр I & $1801-1825$ & 25 & 15038 & 601,5 \\
\hline
\end{tabular}

Составлено по: Золото, его запасы и добыча в русской золотоносной формации. СПб., 1877. С. 119.

Данные из словаря Ф.А. Брокгауза и И.А. Ефрона представлены в табл. 4.

Таблица 4

Добыча золота в Российской Империи, 1741-1820 г., кг

\begin{tabular}{|c|c|c|}
\hline \multirow{2}{*}{ Годы } & \multicolumn{2}{|c|}{ Добыто золота } \\
\cline { 2 - 3 } & Всего & В среднем за период \\
\hline $1741-1760$ & 800 & 40 \\
\hline $1761-1780$ & 1970 & 99 \\
\hline $1781-1800$ & 2610 & 131 \\
\hline $1801-1810$ & 1660 & 166 \\
\hline $1811-1820$ & 3140 & 314 \\
\hline \multicolumn{3}{|c|}{ Справочно (расчет авторов): } \\
\hline $1741-1810$ & 7040 & 101 \\
\hline
\end{tabular}

Составлено по: Энциклопедический словарь. СПб., 1894. Т. 12. С. 649.

Более подробная информация по добыче шлихового и лигатурного золота на Урале и Алтае в период с 1745 по 1813 г., приведенная в таблицах 5-7, основана на публикациях И.Ф. Германа и З.Г. Карпенко. 
«Чистого золота отправлено в Санкт-Петербург на Монетный двор

Таблица 5

с Екатеринбургских золотистых промыслов» с 1754 по 1794 г., кг

\begin{tabular}{|c|c|c|c|c|c|}
\hline Годы & Добыто золота & Годы & Добыто золота & Годы & Добыто золота \\
\hline 1754 & 6,8 & 1768 & 79,8 & 1782 & 64,4 \\
\hline 1755 & 3,9 & 1769 & 69,9 & 1783 & 56,7 \\
\hline 1756 & 1,1 & 1770 & 81,4 & 1784 & 70,2 \\
\hline 1757 & 11,9 & 1771 & 60,3 & 1785 & 62,5 \\
\hline 1758 & 17,2 & 1772 & 44,2 & 1786 & 126,0 \\
\hline 1759 & 16,6 & 1773 & 46,3 & 1787 & 133,0 \\
\hline 1760 & 25,6 & 1774 & 51,2 & 1788 & 127,8 \\
\hline 1761 & 25,7 & 1775 & 66,5 & 1789 & 133,8 \\
\hline 1762 & 23,6 & 1776 & 87,3 & 1790 & 128,6 \\
\hline 1763 & 33,4 & 1777 & 91,3 & 1791 & 129,5 \\
\hline 1764 & 56,4 & 1778 & 97,5 & 1792 & 147,5 \\
\hline 1765 & 52,8 & 1779 & 100,1 & 1793 & 123,8 \\
\hline 1766 & 85,9 & 1780 & 105,0 & 1794 & 135,2 \\
\hline 1767 & 75,9 & 1781 & 67,5 & - & - \\
\hline
\end{tabular}

Составлено по: Герман И.Ф. Сочинения о сибирских рудниках и заводах, СПб., 1797. С. 24.

Таблица 6

«Получено шлиховатого золота при всех трех

Екатеринбургских золотопромываленных заводов» с 1778 по 1791 г., кг

\begin{tabular}{|c|c|c|c|}
\hline Годы & Добыто золота & Годы & Добыто золота \\
\hline 1778 & 140 & 1785 & 100 \\
\hline 1779 & 131 & 1786 & 194 \\
\hline 1780 & 132 & 1787 & 208 \\
\hline 1781 & 87 & 1788 & 213 \\
\hline 1782 & 85 & 1789 & 268 \\
\hline
\end{tabular}

Составлено по: Герман И.Ф. Сочинения о сибирских рудниках и заводах... С. 25-38.

Таблица 7

Выплавка золота в Алтайском горном округе с 1747 по 1815 г., кг

\begin{tabular}{|c|c|c|c|}
\hline Годы & Выплавлено золота & Годы & Выплавлено золота \\
\hline \multirow{2}{*}{$1747-1748$} & \multirow{2}{*}{64} & 1780 & 261 \\
\cline { 2 - 4 } & 73 & 1785 & 342 \\
\hline 1750 & 198 & 1790 & 343 \\
\hline 1765 & 144 & 1795 & 364 \\
\hline 1765 & 346 & 1800 & 309 \\
\hline 1770 & 554 & 1810 & 307 \\
\hline
\end{tabular}


Табл. 7 составлена по: Карпенко З.Г. Горная и металлургическая промышленность Западной Сибири в 1700-1860 гг. Новосибирск, 1963. С. 193.

Представленные в таблице данные по добыче золота в Алтайском горном округе требуют дополнительного изучения по следующим причинам. Во-первых, данные из труда 3.Г. Карпенко говорят о более высокой добыче золота на Алтае, чем в целом по России (см. табл. 2, 3 и 6). Во-вторых, в указанной работе приведены данные за каждые пять лет, основанные на архивных материалах, хранящихся в государственном архиве Алтайского края и государственном архиве Томской области. Согласно информации государственного архива Алтайского края, материалы дела ф. 2. оп. 4. д. 5511 в настоящее время соответствуют делу ф. 2. оп. 1. д. 7035, находятся в плохом физическом состоянии, для работы (полистного просмотра) не выдаются и включены в план работ по реставрации на II квартал 2027 г. Томский государственный архив предоставил информацию о том, что материалы дела ф. 3, оп. 2, д. 583 «Отчеты томского губернатора по управлению городами, учреждениями, подведомственными МВД, сведения губернатора о состоянии учебных заведений, табели о численности и составе населения в губернии» на 713 листах находятся в деле ф. 3. оп. 2. д. 595 и доступны для изучения. Вероятно, после изучения данных архивов станет возможным заполнение ИВР по каждому году рассматриваемого периода.

Добыча золота в Российской империи в период с 1814 по 1917 г. Данные о добыче золота в Российской империи стали публиковаться в официальных статистических сборниках с 1856 г., с уточнениями в последующих изданиях. В них содержится информация о добыче каждого вида золота (шлихового, лигатурного и чистого) начиная с 1814 г., что позволило сформировать три ИВР - по каждому виду золота в отдельности.

ИВР по добыче шлихового золота. В статистическом сборнике Императорского Русского географического общества, вышедшем в свет в 1877 г., указано, что сведения о ежегодной добыче песков и золота в России имеются только с 1859 г. Данные о более ранних периодах не собирались в достаточной полноте, а потому выводы о количестве золота до 1860 г. приблизительны и неполны ${ }^{38}$. В начале XX в. Л.Б. Кафенгаузом была проведена объемная работа по обработке первичных документов по добыче золота в Российской империи с 1887 г., в связи с чем этот период ИВР основан на его труде. Итоговый ИВР по добыче шлихового золота в Российской империи представлен в табл. 8.

Таблица 8

Добыча шлихового золота в Российской империи, 1858-1917 г., кг

\begin{tabular}{|c|c|c|c|c|c|}
\hline Годы & Добыто золота & Годы & Добыто золота & Годы & Добыто золота \\
\hline 1858 & н.д. & 1878 & 42132 & 1898 & 38830 \\
\hline 1859 & н.д. & 1879 & 43093 & 1899 & 38949 \\
\hline 1860 & 24304 & 1880 & 43273 & 1900 & 38778 \\
\hline 1861 & 24589 & 1881 & 36760 & 1901 & 39138 \\
\hline 1862 & 23976 & 1882 & 36156 & 1902 & 34865 \\
\hline 1863 & 23914 & 1883 & 35748 & 1903 & 34710 \\
\hline 1864 & 22907 & 1884 & 35682 & 1904 & 43715 \\
\hline 1865 & 26344 & 1885 & 33016 & 1905 & 39068 \\
\hline 1866 & 27157 & 1886 & 33451 & 1906 & 42750 \\
\hline 1867 & 27021 & 1887 & 34852 & 1907 & 43488 \\
\hline 1868 & 28237 & 1888 & 35150 & 1908 & 50008 \\
\hline 1869 & 33239 & 1889 & 37234 & 1909 & 56795 \\
\hline 1870 & 35507 & 1890 & 39356 & 1910 & 63642 \\
\hline 1871 & 39624 & 1891 & 39079 & 1911 & 61229 \\
\hline 1872 & 37810 & 1892 & 42996 & 1912 & 58219 \\
\hline 1873 & 33332 & 1893 & 44850 & 1913 & 61829 \\
\hline
\end{tabular}

38 Золото, его запасы и добыча в русской золотоносной формации. СПб., 1877. С. 115. 


\begin{tabular}{|c|c|c|c|c|c|}
\hline Годы & Добыто золота & Годы & Добыто золота & Годы & Добыто золота \\
\hline 1874 & 33221 & 1894 & 43937 & 1914 & 61685 \\
\hline 1875 & 32691 & 1895 & 41101 & 1915 & 48093 \\
\hline 1876 & 33319 & 1896 & 37204 & 1916 & 45341 \\
\hline 1877 & 41200 & 1897 & 38196 & 1917 & 30884 \\
\hline
\end{tabular}

Составлено по: 1860-1874, 1876, 1878-1886. Сборник статистических сведений о горнозаводской промышленности России. 1908 г. Пг., 1917, С. 22-23; 1875, 1877. Сборник сведений по России. СПб., 1890. С. 128; 1887-1917. Кафенгауз Л.Б. Эволюция промышленного производства России (последняя треть ХIX в. - 30-е годы ХХ в.) М., 1994. С. 369-370.

ИВР по добыче лигатурного золота. Первоначальные данные о добыче лигатурного золота были аккумулированы в сборнике «Золото, его запасы и добыча в русской золотоносной формации», изданном Императорским Русским географическим обществом. С 1864 г. ежегодные издания о горнозаводской промышленности России публиковались под началом Ученого собрания, призванного выполнять функцию научного центра по вопросам горного дела (первоначально Ученый комитет Корпуса горных инженеров, позднее преобразованный в Горный ученый комитет). Указанные специализированные статистические сборники легли в основу ИВР о количестве добытого лигатурного золота в Российской империи (табл. 9).

Таблица 9

Добыча лигатурного золота в Российской империи, 1814-1900 и 1911 гг., кг

\begin{tabular}{|c|c|c|c|c|c|}
\hline Годы & Добыто золота & Годы & Добыто золота & Годы & Добыто золота \\
\hline 1814 & 264 & 1844 & 20966 & 1874 & 31975 \\
\hline 1815 & 231 & 1845 & 21413 & 1875 & 33646 \\
\hline 1816 & 259 & 1846 & 26400 & 1876 & 30615 \\
\hline 1817 & 298 & 1847 & 28784 & 1877 & 34661 \\
\hline 1818 & 273 & 1848 & 27596 & 1878 & 40738 \\
\hline 1819 & 233 & 1849 & 25998 & 1879 & 41148 \\
\hline 1820 & 321 & 1850 & 23814 & 1880 & 40364 \\
\hline 1821 & 454 & 1851 & 24142 & 1881 & 34173 \\
\hline 1822 & 881 & 1852 & 22388 & 1882 & 36156 \\
\hline 1823 & 1731 & 1853 & 23975 & 1883 & 33213 \\
\hline 1824 & 3372 & 1854 & 26154 & 1884 & 33413 \\
\hline 1825 & 3889 & 1855 & 27017 & 1885 & 30598 \\
\hline 1826 & 3788 & 1856 & 27118 & 1886 & 32146 \\
\hline 1827 & 4617 & 1857 & 28397 & 1887 & 33715 \\
\hline 1828 & 4764 & 1858 & 28020 & 1888 & 34231 \\
\hline 1829 & 4745 & 1859 & 25207 & 1889 & 36037 \\
\hline 1830 & 6268 & 1860 & 24431 & 1890 & 38330 \\
\hline 1831 & 6587 & 1861 & 23851 & 1891 & 37900 \\
\hline 1832 & 6925 & 1862 & 23927 & 1892 & 41419 \\
\hline 1833 & 6714 & 1863 & 23907 & 1893 & 43456 \\
\hline 1834 & 6635 & 1864 & 22899 & 1894 & 41639 \\
\hline 1835 & 6436 & 1865 & 25819 & 1895 & 40173 \\
\hline 1836 & 6652 & 1866 & 27183 & 1896 & 36036 \\
\hline 1837 & 7249 & 1867 & 27021 & 1897 & 36960 \\
\hline 1838 & 8078 & 1868 & 28034 & 1898 & 37128 \\
\hline 1839 & 8121 & 1869 & 33127 & 1899 & 37791 \\
\hline 1840 & 7502 & 1870 & 34874 & 1900 & 37670 \\
\hline 1841 & 10588 & 1871 & 38789 & \multicolumn{2}{|c|}{ 1901-1910 - н.д. } \\
\hline 1842 & 14891 & 1872 & 37708 & 1911 & 39268 \\
\hline 1843 & 20335 & 1873 & 37151 & \multicolumn{2}{|c|}{ 1912-1917 - н.д. } \\
\hline
\end{tabular}


Табл. 9 составлена по: 1814-1829 и 1864-1869. Золото, его запасы и добыча в русской золотоносной формации. СПб., 1877. С. 115-116; 1830-1863. Сборник статистических сведений по горной части на 1866 год. СПб., 1866. С. 2-3; 1870-1879. Горнозаводская производительность России в 1879 году. СПб., 1881. С. $46 ; 1880$. Горнозаводская производительность России в 1880 году. СПб., 1882. С. 46; 1881. Горнозаводская производительность России в 1881 году. СПб., 1883. С. 49; 1882. Горнозаводская производительность России в 1882 году. СПб., 1884. С. 8; 1883. Горнозаводская производительность России в 1883 году. СПб., 1885. С. 6; 1884. Горнозаводская производительность России в 1884 году. СПб., 1886. С. 5; 1885. Горнозаводская производительность России в 1885 году. СПб., 1887. С. IV; 1886. Сборник статистических сведений о горнозаводской промышленности России в 1886. СПб., 1888. С. ХІ; 1887. Сборник статистических сведений о горнозаводской промышленности России в 1887. СПб., 1890. С. Х; 1888. Сборник статистических сведений о горнозаводской промышленности России в 1888 году. СПб., 1891. С. Х; 1889. Сборник статистических сведений о горнозаводской промышленности России в 1889 году. СПб., 1892. С. VI; 1890. Сборник статистических сведений о горнозаводской промышленности России в 1890 заводском году. СПб., 1892. С. V; 1891. Сборник статистических сведений о горнозаводской промышленности России в 1891 заводском году. СПб., 1893. С. XV; 1892. Сборник статистических сведений о горнозаводской промышленности России в 1892 заводском году. СПб., 1895. С. 4; 1893. Сборник статистических сведений о горнозаводской промышленности России в 1893 заводском году. СПб., 1896. С. IV; 1894. Сборник статистических сведений о горнозаводской промышленности России в 1894 заводском году. СПб., 1896. С. III; 1895. Сборник статистических сведений о горнозаводской промышленности России в 1895 заводском году. СПб., 1897. С. V; 1896. Сборник статистических сведений о горнозаводской промышленности России в 1896 заводском году. СПб., 1899. С. IV; 1897. Сборник статистических сведений о горнозаводской промышленности России в 1897 заводском году. СПб., 1899. С. V; 1898. Сборник статистических сведений о горнозаводской промышленности России в 1898 заводском году. СПб., 1900. C. VIII; 1899. Сборник статистических сведений о горнозаводской промышленности России в 1899 году. СПб., 1901. С. VII; 1900. Сборник статистических сведений о горнозаводской промышленности России в 1900 году. СПб., 1903. С. V; 1911. Сборник статистических сведений о горнозаводской промышленности России в 1911 году. СПб., 1918. С. VII.

ИВР по добыче чистого золота. Научная база для изучения статистических сведений по различным разделам науки была заложена в первом сборнике статистических сведений о России ${ }^{39}$, в предисловии к которому отмечено, что основным правилом при составлении такого рода публикаций является использование наиболее достоверных и современных данных. Этот же подход был применен и к составлению временного ряда по добыче чистого золота, который впоследствии был воспринят в ежегодных статистических сборниках о горнозаводской промышленности в России. Именно эти труды составили основу ИВР о ежегодном получении чистого золота (табл. 10).

Таблица 10

Добыча чистого золота в Российской империи, 1814-1917 гг., кг

\begin{tabular}{|c|c|c|c|c|c|}
\hline Годы & Добыто золота & Годы & Добыто золота & Годы & Добыто золота \\
\hline 1826 & 3879 & 1845 & 20114 & 1896 & 32605 \\
\hline 1827 & 4643 & 1846 & 25021 & 1897 & 33399 \\
\hline 1828 & 4789 & 1847 & 27887 & 1898 & 33391 \\
\hline 1829 & 4733 & 1848 & 27170 & 1899 & 33702 \\
\hline 1830 & 5666 & 1849 & 25091 & 1900 & 33621 \\
\hline 1831 & 5945 & $1850-1882$ & н.д. & 1901 & 34256 \\
\hline 1832 & 6151 & 1883 & 30273 & 1902 & 33495 \\
\hline 1833 & 6113 & 1884 & 30775 & 1903 & 36337 \\
\hline 1834 & 6064 & 1885 & 28138 & 1904 & 31188 \\
\hline 1835 & 6152 & 1886 & 28173 & 1905 & 31205 \\
\hline 1836 & 6304 & 1887 & 31088 & 1906 & 31221 \\
\hline 1837 & 6923 & 1888 & 31492 & 1907 & 31238 \\
\hline 1838 & 7759 & 1889 & 33131 & 1908 & 31254 \\
\hline 1839 & 7746 & 1890 & 35311 & 1909 & 31270 \\
\hline 1840 & 8742 & 1891 & 34801 & 1910 & 31287 \\
\hline
\end{tabular}

\footnotetext{
${ }^{39}$ Сборник статистических сведений о России, издаваемый статистическим отделением Императорского
} Русского географического общества. Книжка 1. СПб., 1851. Табл. 3 к С. 1. 


\begin{tabular}{|c|c|c|c|c|c|}
\hline Годы & Добыто золота & Годы & Добыто золота & Годы & Добыто золота \\
\hline 1841 & 10217 & 1892 & 37965 & 1911 & 31303 \\
\hline 1842 & 14155 & 1893 & 39684 & 1912 & 31320 \\
\hline 1843 & 19140 & 1894 & 37887 & 1913 & 31336 \\
\hline 1844 & 19665 & 1895 & 36414 & $1914-1917$ & н.д. \\
\hline
\end{tabular}

Составлено по: 1826-1849. Сборник статистических сведений о России, издаваемый статистическим отделением Императорского Русского географического общества. Книжка 1. СПб., 1851.Табл. № 3 к С. 22 ; $1883-$ 1887. Сборник статистических сведений о горнозаводской промышленности России в 1892 г., 1895. С. 4; 18881898. Сборник статистических сведений о горнозаводской промышленности России в 1898 заводском году. СПб., 1900. С. VIII; 1899-1900. Сборник статистических ведений о горнозаводской промышленности России в 1908 году. Ч. ІІ. Таблицы. СПб., 1910. С. 21; 1901-1903. Сборник статистических сведений о горнозаводской промышленности России в 1911 году. Пг., 1918. С. VII; 1904-1913. Общий обзор главных отраслей горной и горнозаводской промышленности: особое приложение к смете Горного департамента на 1916 г. Пг., 1915. С. 4.

Выводы. Составление ИВР по добыче золота в Российской империи за период с 1745 по 1917 г. позволило опробовать на практике ряд методологических аспектов составления ИВР, которые входят в единую методологию подготовки ИВР:

- определение начальной и конечной даты ИВР на основе изучения различных источников информации, содержащих исторические сведения о начале деятельности золотодобывающей промышленности в Российской империи, исходя из различных периодизаций исторических процессов, а также конкретных исторических событий;

- обеспечение достоверности ИВР путем использования как общепринятых критериев достоверности (единая методология сбора и обработки первичных данных), так и специфического именно для ИВР критерия достоверности (использование наиболее достоверных источников исторической статистической информации, а также приведение библиографических ссылок на каждый уровень временного ряда, для того чтобы в последующем исследователи могли проверить и в случае необходимости скорректировать ранее составленные ИВР);

- обеспечение сопоставимости данных при формировании ИВР за счет использования единых единиц измерения, одинаковых временных интервалов и пространственной базы.

Применение указанных выше методологических подходов позволило сделать вывод о том, что в настоящее время невозможно составление единого ИВР по добыче золота в Российской империи: данные по добыче золота до 1814 г. настолько несопоставимы, что в таких обстоятельствах целесообразно разделить ИВР на два временных периода (1745-1814 и 1814-1917 гг.).

В работе представлены данные по добыче каждого вида золота: шлихового - с 1858 г., лигатурного - с 1814 г. и чистого золота - с 1826 г., а также проведен их первичный анализ, что позволяет наметить несколько направлений дальнейшего исследования показателей добычи золота:

- изучение архивных материалов, среди которых наиболее интересными представляются материалы Государственных архивов Алтайского края и Томской области;

- заполнение ИВР по добыче золота недостающими данными, в частности, периодов 1745-1814 гг. и начала XX в.

\section{Лumepamypa}

Борхвальдт О.В. Словарь золотого промысла Российской империи. М.: Русский путь, 1998. 240 c.

Винокуров М., Суходолов А. Золотопромышленность дореволюционной Сибири // ЭКО. 1996. № 5. 206-214 с.

Гакман И.Ф. Краткое землеописание Российского государства. СПб., 1787. С. 37.

Карпенко 3.Г. Горная и металлургическая промышленность Западной Сибири в 17001860 годах / Акад. наук СССР. Сиб. отд-ние. Новосибирск: Изд-во Сиб. отд-ния АН СССР, 1963. 215 с.

Максимов М. М. Очерк о золоте. М.: Недра, 1988. 111 с. 
Марфунин А.С. История золота. М.: Наука, 1987. 245 с.

Митин А.И. Кабинетская золотопромышленность Алтайского (горного) округа: 18301917: дис. ... канд. ист. наук. Барнаул, 2003. 255 с.

Мякишев М.Н. Зарождение и развитие разведки и добычи россыпного золота в Алтайском горном округе в период его аренды Министерством финансов: 1830-1855 гг.: дис. ... канд. ист. наук. Кемерово, 2011. 196 с.

О-Ун-Дар К.У. Золотопромышленность Енисейской губернии с 1832 по 1917 год: дис. ... канд. ист. наук. Красноярск, 2003. 284 с.

Рукосуев Е.Ю., Курлаев Е.А., Шумкин Г.Н. Горнозаводская промышленность Урала в XVIII - начале XX века: благородные металлы. Екатеринбург: УрО РАН, 2020. 320 с.

Рукосуев Е.Ю., Шумкин Г.Н. Золотодобывающая промышленность Урала середины XVIII - начала XX века: периоды развития // Исторический курьер. 2020. № 1 (9). С. 7-21. URL: http://istkurier.ru/data/2020/ISTKURIER-2020-1-01.pdf

Сапоговская Л.В. Золотопромышленность Республики Советов - СССР - РФ: эволюция отрасли в альтернативных системах хозяйствования // Экономическая история. Ежегодник. 2003. М.: РОССПЭН, 2004. С. 266-308.

Симчера В.М. Энциклопедия статистических публикаций. Х-XX вв. / В.М. Симчера, В.А. Соколин, Е.А. Машихин, А.Ю. Шевяков. М.: Финансы и статистика. 2001. 992 с.

Суходолов А.П. Исторические этапы и экономико-географические предпосылки промышленного развития Иркутской области и Восточной Сибири // Иркутский историко-экономический ежегодник: 2015. Иркутск, 2015. С. 30-43.

Суходолов А.П. История иркутской золотодобычи // Золото и технологии. 2017. № 4 (38). C. $150-162$.

Шарапов И.П. Очерки по истории Ленских золотых приисков. Иркутск: Иркутское областное издательство, 1949. 203 с.

Шумилин О.В., Шумилина В.О. Доходы и расходы государственного бюджета Русского Царства и Российской империи за 1680-1917 гг. // Аудит и финансовый анализ. 2018. № 5. С. 203-209.

Тарасенко-Отрешков Н.И. О золоте и серебре: происхождении их, количестве добытом во всех известных странах света с глубокой древности по 1855 год; ныне существующем их накоплении в главнейших государствах и взаимном отношении золота к серебру по их весу и ценности. СПб., 1856.

\section{References}

Borkhvaldt, O.V. (1998). Slovar' zolotogo promysla Rossiiyskoiy Imperii [Dictionary of the Gold Craft of the Russian Empire]. Moscow, Russkiy put. 240 p.

Gakman, I.F. (1787). Kratkoe zemleopisanie Rossiyskogo gosudarstva [Brief Land Description of the Russian State]. St. Petersburg, p. 37.

Karpenko, Z.G. (1963). Gorhaya i metallugicheskaya promyshlehhost' Zapadnoiy Sibiri [Mining and Metallurgical Industry of Western Siberia in 1700-1860]. Novosibirsk, Sibirsoe otdelenie Akademii nauk SSSR. 215 p.

Maksimov, M. M. (1988). Ocherk o zolote [Essay on Gold]. Moscow, Nedra. 111 p.

Marfunin, A.S. (1987). Istoriya zolota [The History of Gold]. Moscow, Nauka. 245 p.

Mitin, A.I. (2003). Kabinetskaya zolotopromyshennost' Altaiyskogo (gornogo) okruga: 1830 1917 [Cabinet Gold Mining of the Altai (Mining) District: 1830-1917], Cand. ist. sciences. Barnaul. 255 p.

Myakishev, M.N. (2011). Zarogdenie I razvitie razvedki i dobychi rossypnogo zolota v Altaiyskom gornom okruge v period ego arendy Ministerstvom Finansov: 1830-1855 [The Origin and Development of Prospecting and Mining of Alluvial Gold in the Altai Mining District Dduring the Period of its Lease by the Ministry of Finance: 1830-1855], Cand. ist. sciences. Kemerovo. 196 p.

O-Un-Dar, K.U. (2003). Zolotopromyshennost' Eniseiyskoiy gubernii s 1832 po 1917 [Gold Mining of the Yenisei Province From 1832 to 1917], Cand. ist. sciences. Krasnoyarsk. 284 p. 
Rukosuev, E.Yu., Kurlaev, E.A., Shumkin, G.N. (2020). Gornozavodskaya promyshennost Urala v 18 - nachale 20 veka: Blagorodnye metally [Mining Industry of the Urals in the $18^{\text {th }}-$ Early $20^{\text {th }}$ Centuries: Noble Metals]. Yekaterinburg, Ural'skoe otdelenie Rossiiyskoiy Academii nauk, 2020. 320 p.

Rukosuev, E.Yu., Shumkin, G.N. Zolotodobyvayushchaya promyshennost' Uala serediny $X V I I I$ - nachala XX veka: periody razvitiya [Gold Mining Industry of the Urals in the mid-18 ${ }^{\text {th }}-$ Early $20^{\text {th }}$ Centuries: Periods of Development]. In Istoricheskiy kurier. No. 1 (9), pp. 7-21. URL: http://istkurier.ru/data/2020/ISTKURIER-2020-1-01.pdf

Sapogovskaya, L.V. (2003). Zolotopromyshennost' Respubliki Sovetov - SSSR - RF: evolyutsiya otrasli $v$ al'ternativnykh sistemakh hozyaiystvovaniya [Gold Industry of the Republic of Soviets - USSR - RF: Evolution of the Industry in Alternative Economic Systems]. In Economichskaya istoriya. Egegodnik. Moscow, pp. 266-308.

Sharapov, I.P. (1949). Ocherki po istorii Lenskikh priiskov [Essays on the History of the Lena Gold Mines]. Irkutsk, Irkutskoe oblastnoe izdatel'stvo. 203 p.

Shumilin, O.V., Shumilina, V.O. (2018). Dochody i raschody gosudarstvennogo byudzheta Russkogo Tharstva I Rossiiyskoiy Imperii za 1680-1917 gg. [Revenues and Expenditures of the State Budget of the Russian Kingdom and the Russian Empire for 1680-1917]. In Audit $i$ finansovyy analyz. No. 5, pp. 203-209.

Simchera, V.M., Sokolin, V.A., Mashikhin, E.A., Shevyakov, A. Yu. (2001). Entsiklopediya statisticheskikh pulikatsiiy. 10-20 veka [Encyclopedia of Statistical Publications. $19^{\text {th }}-20^{\text {th }}$ Centuries]. Moscow, Finansy i statistica. 992 p.

Sukhodolov, A.P. (2015). Istoricheskie etapy i ekonomiko-geograficheskie predposylki promyshlennogo razvitiya Irkutskoiy oblasti I Vostochnoiy Sibiri [Historical Stages and Economic and Geographical Prerequisites for the Industrial Development of the Irkutsk Region and Eastern Siberia]. In Irkutskiy Istoriko-economicheskiy ezhegodnik. Irkutsk, pp. 30-43.

Sukhodolov, A.P. (2017). Istoriya irkutskoiy zolotodobychi [History of Irkutsk Gold Mining]. In Zoloto I tekhnologii. No. 4 (38), pp. 150-162.

Vinokurov, M., Sukhodolov, A. (1996). Zolotopromyshennost' dorevolyutsionnoy Sibiri [Gold Industry of Pre-Revolutionary Siberia]. In EKO. No. 5, pp. 206-214.

Tarasenko-Otreshkov, N.I. (1856). O zolote i serebre: proiskhozhdenii ikh, kolichestve dobytom vo vsekh izvestnykh stranakh sveta s glubokoy drevnosti po 1855 god; nyne sushchestvuyushchem ih nakoplenii v glavneyshikh gosudarstvakh i vzaimnom otnoshenii zolota k serebru po ikh vesu i tsennosti [On Gold and Silver: their Origin, the Amount Extracted in all Known Countries of the World from Ancient Times to 1855; their Current Accumulation in the Main States and the Mutual Ratio of Gold to Silver by their Weight and Value]. St. Petersburg.

Статья поступила в редакцию 25.05.2021. г. 